\title{
СТЬКЛОВИДНО ТЯЛО. АНАТОМИЧНИ ОСОБЕНОСТИ. ПЪРВИЧНО ПЕРСИСТИРАЩО СТЬКЛОВИДНО ТЯЛО
}

\author{
Видинова Хр.
}

Очна клиника В.М.А., София

Известно е, че стъкловидното тяло представлява $2 / 3$ от масата на очната ябълка То изпълва вътрешността на окото и е разположено зад лещата и пред ретината (1, 6). То представлява прозрачно, желеподобно, безцветно тяло, което участвува в оптичния апарат на окото и поддържа тонуса и формата му.

Стъкловидното тяло има обем от 3,5- 4 cm3 и тежи около 4 g. Структурно то се разделя на периферна (хиалоидна мембрана и кортекс) и централна част (клокетов канал и трактуси).

Фиг. 1. Анатомичен вид на нормалното стъкловидно тяло. Виждат се добре централната и периферна част и Клокетовия канал, през който в ембрионалното развитие минава артерия хиалоидея.

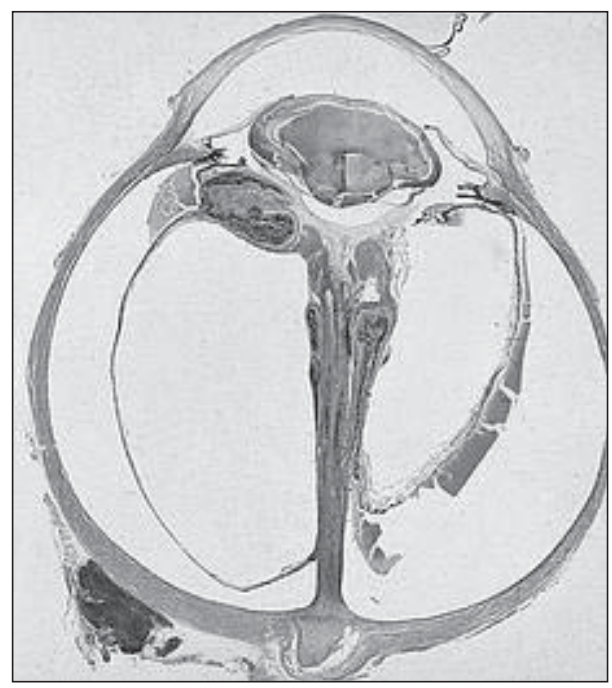

Структурата на стькловидното тяло е изследвана с най- различни изследователски методи: физични, биохимични, морфологични, дори клинични - оптичната кохерентна томография. Стъкловидното тяло представлява 55\% от съдържимото на очната ябълка, изпълва вътрешността и и представлява прозрачно, желеподобно, безцветно тяло, което като амортисьор предпазва вътреочните структури от травми (2). Състои се от две основни части - витреален кортекс и централна част, където се намира Клокетовия канал. Витреалният кортекс е изграден от пльтна колагенна мрежа и свързан здраво с ретината в областта на базата на ст. тяло. Базата на стькловидното тяло се дели на абсолютна и относителна $(3,9)$. Абсолютната част на базата на стъкловидното тяло е областта на неговото прикрепване към ora serrata. Относителната част на базата на стъкловидното тяло има предна и задна граница (11). Предната граница - basis vitrei ciliaris обхваща областта на прикрепване на стъкловидното тяло към цилиарния епител на 1-2 мм пред ora serrata, почти до средата на Pars plana ciliaris. Задната граница на относителната част на базата на стъкловидното тяло - basis vitrei retinalis e зоната на възрастовата фиксация на стъкловидното тяло към ретината, тя се намира на 2-3 мм зад ora serrata и с възрастта се измества към екватора (4). Тя е и мястото на най-здраво свързване на стъкловидното тяло към ретината, затова е и най-честото място на разкъсвания на ретината. Електронната микроскопия доказа, че 
задната повърхност на стъкловидното тяло не е отграничена от специална мембрана, а имаме обща витрео-ретинна повърхност като витреалните фибрили се вплитат директно в membrane limitans interna и клетъчната мембрана на Мюлеровите клетки (7).

Централната част на стькловидното тяло обратно на кортикалната е изградена от фина мрежа от колагенни влакна и почти липсват клетъчни елементи , което обуславя нейната прозрачност. В центъра се намира Клокетовия канал, S образна цепка, свързваща задния полюс на лещата с диска на зрителния нерв, тук през ембрионалното развитие се е разполагала a. hyaloidea, участвуваща в кръвоснабдяването на лещата (7).

В централната част се разполагат и витреалните трактуси- мембранули. Това са влакнести структури с висока механична здравина, които могат да предават тракции върху ретината. Различават се четири витреални трактуси- преретинен, медиален, коронарен и хиалоиден. Както всяка съединително тъканна структура, така и стъкловидното тяло е изградено от малко количество клетки, разположени в кортекса и голямо количество елементи на междуклетъчния матрикс (8).

\section{Структурата на стькловидното тяло може да се определи по следния начин:}

a) хиалоцити, витреални кортексни клетКи

б) междуклетъчен матрикс-колаген тип II, протеогликани, малки протеини

в) хиалуронова киселина.
Фиг. 2. Схематично изображение на стъкловидното тяло и неговия строежколегенни влакна и хиалуронова киселена. Схема на B.Wood.

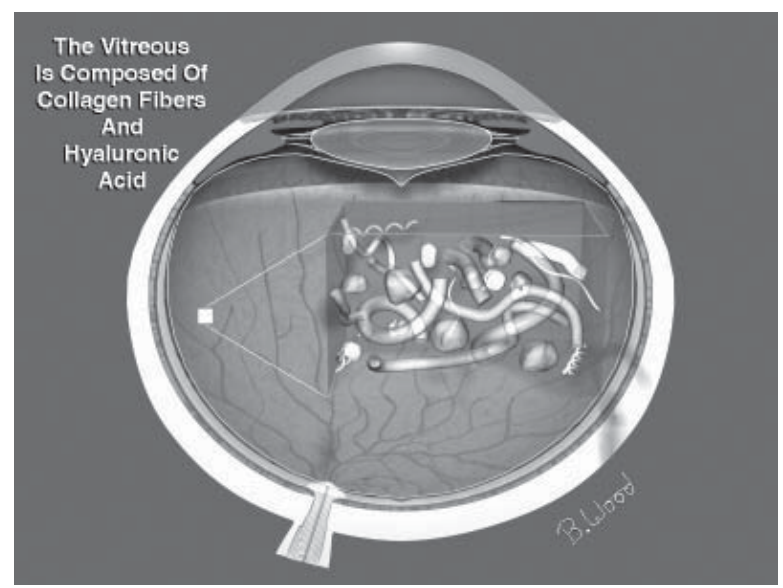

Стъкловидното тяло представлява една високоспециализирана съединително-тъканна структура. Както всяка съединителна тъкан то е изградено от малко количество клетки и обилен междуклетъчен матрикс. Съдържа сравнително малко по брой клетки и те са разположени предимно в неговата кортикална част, близо до ретината. В стъкловидното тяло се открива скелет, съставен от фини колагенни влакна с дебелина $25 \mathrm{~nm}$, свързани с протеогликанови комплекси в плътна и устойчива мрежа, свързани още с кисели мукополизахариди и хиалуронова киселина. Всяка загуба на връзката между тези структури води до нестабилност на структурата, нейната деструкция и условия за патологични състояния (5). Около 99 \% от съдържимото на стъкловидното тяло е вода, свързана с мукополизахариди и протеини и $1 \%$ е сухо вещество. Най-важният мукополизахарид е хиалуроновата киселина, която обуславя пластичността на витреалния гел и нейната концентрация се променя с възрастта. Налични са и разтворими белтъци, които отговарят на албуминовата 
и глобулиновата фракция на кръвния серум, но са в стократно по-малки количества (12).

Клетките на стъкловидното тяло носят различни имена- витреални клетки, витреални кортексни клетки, витреоцити, хиалоцити. Произходът на витреоцитите остава спорна тема и до сега. Според редица автори те имат мезенхимен характер и това обяснява способността им активно да синтезират колаген и други елементи на междуклетьчния матрикс. Според други автори обаче по своите ултраструктурни характеристики хиалоцитите приличат много на кръвните моноцити и именно за това могат да участват активно във фагоцитозата на кръвните елементи при хемофталм в стъкловидното тяло. Все повече се налага становището, че хиалоцитите и фибробластите представляват един и същи вид клетки, намиращи се в различни функционални стадии (12).

Фиг. 3 Електронно микроскопска снимка на хиалоцитите на стъкловидното тяло.

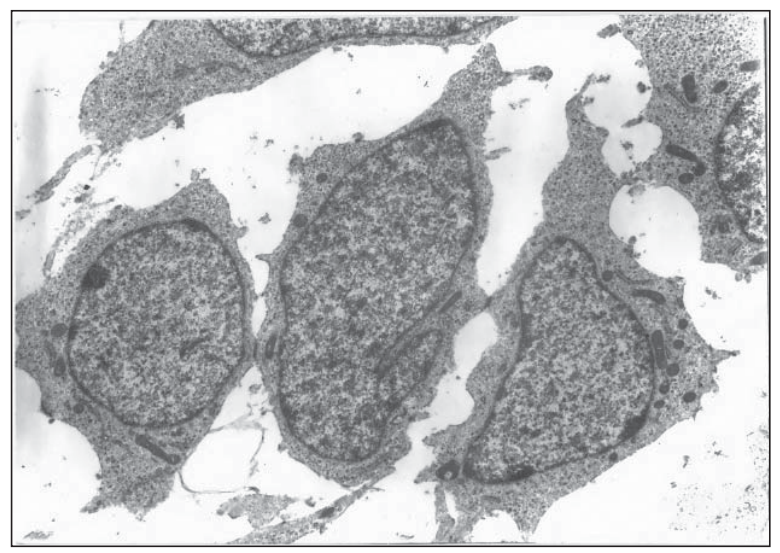

Хиалоцитите синтезират хиалуронова киселина и имат изразена фагоцитарна функция. Счита се също, че през ембрионалното развитие са участвували в синтезата на колагеновите влакна на стъкловидното тяло. Те са клетки с изразена метаболитна активност и съдържат голямо количиство митохондрии в своята цитоплазма.

Колагенните влакна на стъкловидното тяло са с размер $25 \mathrm{~nm}$, образуващи с помощта на протеогликанови комплекси, хидрофилни кисели мукополизахариди и хиалуронова киселина стабилна мрежа. Всяка загуба на връзката между тези структури води до деструкция на стъкловидното тяло.

Поради липсата на кръвоносни съдове обмяната на веществата в стъкловидното тяло е силно забавена. Постъпват вещества чрез дифузия от преднокамерната течност и отпадни продукти от ретината и частично от лещата (13).

Прозрачността на стъкловидното тяло се обуславя от три бариери, които не пропускат клетъчните елементи от кръвта. Това са стените на кръвоносните съдове на ретината, които са непропускливи за кръвни елементи, вътрешната гранична мембрана на ретината и кортикалния слой на стъкловидното тяло, който представлява т. нар. молекулярно сито (5).

\section{Основните функции на структурата са :}

1. Поддържа тонуса на окото.

2. Играе ролята на амортисьор при движението на очната ябълка . Предпазва очните структури от травма.

3. Участвува в диоптричния апарат на окото с индекс на пречупване от 1.33 .

4. Участвува в обмяната на веществата на очните тъкани.

\section{Заболявания на стъкловидното тяло.}

Най- общо заболяванията на стъкловидното тяло могат да се класифицират по следния начин:

1. Вродени аномалии на стъкловидното тяло. Персистиращо хиперпластично първично стъкловидно тяло.

2. Дегенеративни процеси, сварзани със 
стареенето на стъкловидното тяло. Фибрилерна деструкция на стъкловидното тяло. Задно отлепване на стъкловидното тяло.

3. Витреални тракционни синдроми. Първичен витрео-ретинен тракционен синдром на Джеффе. Вторичен витрео-ретинен тракционен синдром на Ирвин-Гас.

\section{4. Пролиферативна витреоретинопатия.}

\section{5. Кръвоизливи в стъкловидното тяло.}

6. Възпаления в стъкловидното тяло. Ендофталмит.

Всички тези състояния са малко или много свързани с анатомичните особености на стъкловидното тяло с неговия забавен метаболизъм и бариерни функции, което обуславя и особеностите на протичане на отделните заболявания.

Вродени аномалии на стъкловидното тяло.Персистиращо хиперпластично първично стъкловидно тяло.

\section{Определение:}

Вродено състояние, което се дължи на задръжка в обратното развитие на хиалоидната съдова мрежа през ембрионалния период. Налице е пълно или частично персистиране на ембрионалната васкуларна система на стъкловидното тяло. Състоянието се развива при нормално протекла бременост и раждане и не е свързано с възпалителни реакции (5).

\section{Клинична картина:}

Налице са следните особености- едностранен -микрофталм- окото изглежда по-малко.

Левкокория- бяла зеница (Фиг.4)

Фиг. 4. Левкокория при персистиращо първично хиперпластично стъкловидно тяло.

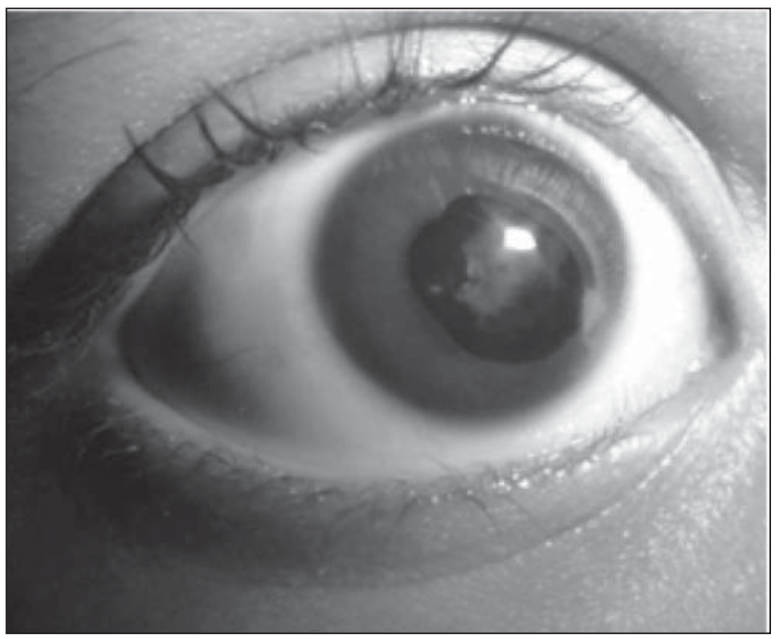

\section{Намалено зрение}

При обективното изследване на широка зеница се наблюдава зад зеницата белезникава фиброваскуларна тъкан с радиерно разположени кръвоносни съдове в нея. Налице е издърпване и удължаване на цилиарните израстъци към мембраната. Може да се наблюдава част от запазена хиалоидна мембрана- vasa hyaloidea propria като белезникаво повлекло от задния полюс на лещата към папилата на зрителния нерв. В задния полюс обикновено не се наблюдават промени, но може да са налице гънки на ретината и аномалии в ретинната съдова мрежа $(1,13)$. 
(Фиг. 5) При обективното изследване на широка зеница се открива мембрана със собствена съдова мрежа, остатък от съдовата система на нерезирбираната артерия хиалоидея. / снимка от Kanski/

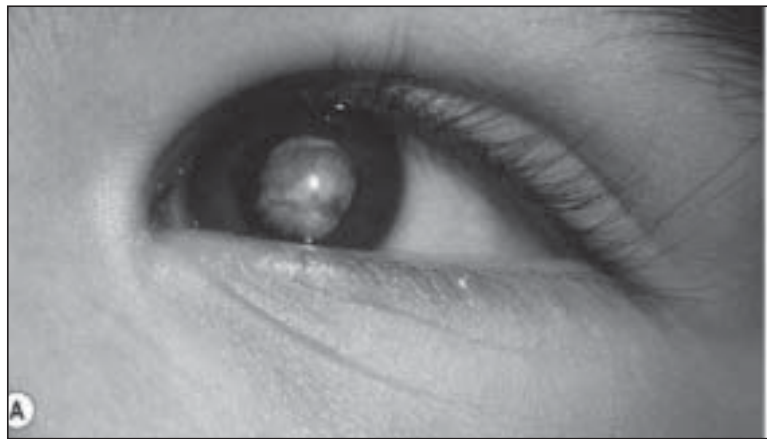

Освен разгърнатата картина, често се наблюдават и така наречените минимални форми, при които се наблюдават единични дефекти главно по лещата във вид на дъга, петно, малка белезникава лента от задната лещена капсула, движеща се свободно към кухината на стъкловидното тяло. Може да се наблюдава и минимална лезия на повърхността на папилата, но е доста по-рядко. В тези случаи зрението е малко нарушено и прогнозата е доста по-добра (10).

(Фиг. 6) „Минимални форми” на персистиращо хиперпластично стъкловидно тяло. Остатък от артерия хиалоидея се наблюдава от папилата на зрителния нерв към кухината на стъкловидното тяло.

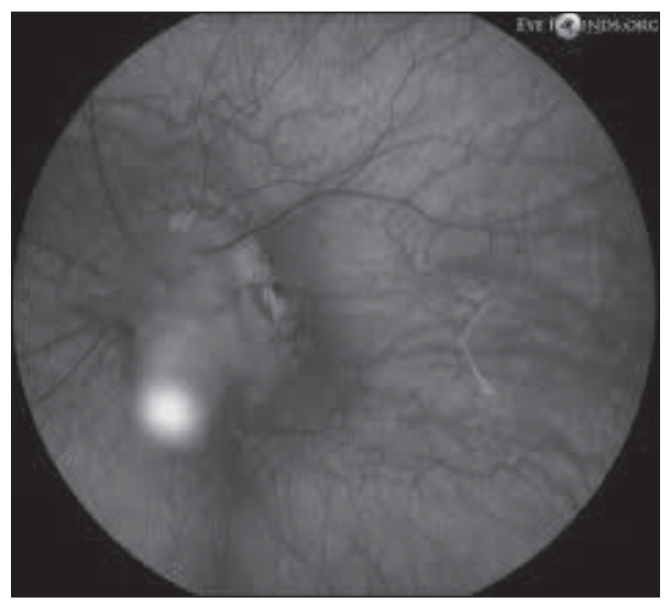

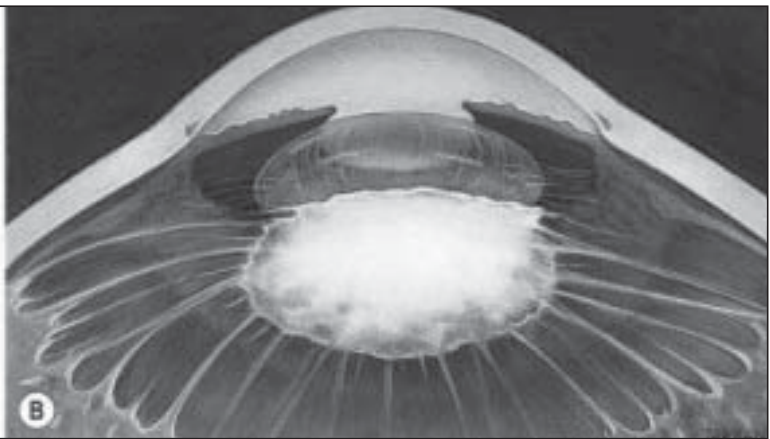

Усложнения:

Заболяването бързо еволюира до различни усложнения.

Много бързо се развива катаракта-с изцяло помътняване на лещата и силно спадане на зрителната острота.

Не са редки и хеморагиите в стъкловидното тяло, които са рецидивиращи и почти никога не се резорбират. Бързо се организират и водят до тракционно увреждане на ретината. $\mathrm{He}$ рядко се развива и глаукома $(3,13)$.

\section{Диференциална диагноза:}

Добре е да се направи диференциална диагноза на левкокорията в детска възраст, като се изключат следните състояния:

1. Ретинобластом

2. Дисплазията на Рииз.

3. Вродена катаракта.

4. Болестта на Norrie.

\section{Лечение:}

Единствено оперативно- витректомия. 


\section{Книгопис}

1. Ali I.U., Mauthner V., Lanza R., Hynes R.O. Restoration of normal morphology, adhesion and cytoskeleton in transformed cells by addition of a transformation - sensitive surface protein. Cell 11, 1977, 115-126

2. Beck K, Hunter I, Engel J. Structure and function of laminin: Anatomy of a multidomain glycoprotein. FASEB J 4, 1990,148-160

3. Bellhorn M.B., Friedman A.H., Wise G.N., Henkind P. Ultrastructure and clinicopathologic correlation of idiopathic preretinal macular fibrosis. Am J Ophtalmol 79,1975,366-373.

4. Casaroli Marano, Senen Vilaro; The role of fibronectin, laminin, vitronectin and their receptors on cellular adhesion in PVR. . Invest. Ophthalmology Vis. Sci.1994; 35; 2791-2801.

5. CharterisD.Proliferativevitreorethinopaty: pathology, surgical managment, and adjunctive treatment. British J.Ophtalm. 79,1995,953-960.

6. Constable I., Ogury M., Chesny C. Plateletinduced vitrous membrane formation. Invest Ophtalmol 12,1973,680.

7. Cote R.J., Thompson T.M.,Cordon-
Cardo C. Intermediate filaments. In Immunocytochemistry in Tumor Diagnosis, Russo J, editor.Boston, Nijhoff, 1984,pp.72-82.

8. Francois J., Victoria-Troncoso V., Eeckhout M. Histochemical studies of hialocytes in tissue culture.Ophtalm.Res. 5,1973,215.

9. Furie M.B., Rifkin D.B. Proteolyticali derived fragments of human plasma fibronectin and their location within intact molecule. J Biol Chem. 255, 1980,3134-3140.

10. Kurkinen M., Vahery A., Roberts P.,Stenman S. Sequential appearence of fibronectin and collagen in experimental granulation tissue. Lab.Invest. 43, 1980, 47-51.

11. Moll R., Franke W.W., Schiller D.L.,Geiger B.,Krepler $R$. The catalog of human cytoceratins : Patterns of expressionin normal epithelia,tumors, and cultured cells. Cell 31,1982,11.

12. Pearlstein E., Gold L.I., Garcia-Pardo A. Fibronectin: a review of its structure and biological activity. Mol Cell Biochem 29,1980,103-128.

13. Pirie A.,Schmidt G., Waters J.W. Ox vitreous humour:residual protein. Br J Ophtalmol 32,1948.321-330. 


\section{ВЪПРОСИ КЪМ СТЬКЛОВИДНО ТЯЛО. АНАТОМИЧНИ ОСОБЕНОСТИ. ПЪРВИЧНО ПЕРСИСТИРАЩО СТЬКЛОВИДНО ТЯЛО}

\section{1. Стъкловидното тяло представлява ............. от масата на очната ябълка.}

A-2/3 от масата на очната ябълка.

B- $1 / 2$ от масата на очната ябълка.

C- 4/5 от масата на очната ябълка.

\section{2. Кое от изброените за стъкловидното тяло не е вярно:}

А- Представлява прозрачно, желеобразно, безцветно тяло , което като амортисьор предпазва очните структури от травма.

B- Състои се от периферна част и Клокетов канал.

C- Представлява 55\% от съдържимото на очната ябълка.

Д- Има малко количество клетки и голямо количество елементи на междуклетъчния матрикс.

\section{3. Клетките на стъкловидното тяло- витреоцитите се намират в:}

А. Централната част на стъкловидното тяло.

В. Клокетовия канал

C. Най-вече в периферната част на стъкловидното тяло в близост до ретината.

\section{4. Хиалуроновата киселина отговаря за:}

А. Пластичността на витреалния гел.

В. Ригидността на стъкловидното тяло.

С. Амортисьорния му ефект.

\section{5. Концентрацията на хиалуронова киселина :}

А. се променя с възрастта.

В. не се променя с възрастта.

\section{6. Прозрачността на стъкловидното тяло се дължи на:}

А. Непропускливостта на стените на ретинните съдове.

В. Вътрешната гранична мембрана.

С. Структурата на кортикалния слой.

Д. Не пропускливостта на съдовете на хориоидеята.

Е. Изброеното в А,B, С. 


\section{7. Персистиращо хиперпластично стькловидно тяло се среща при:}

А. Задържане в обратното развитие на хиалоидната съдова мрежа през ембрионалния период.

В. При нормално протекла бременост и раждане.

C. Не е свързана с развитието на възпалителни процеси в стъкловидното тяло.

Д. Всичко от изброеното е вярно.

8. Какво се наблюдава при минималните форми на Персистиращо хиперпластично стъкловидно тяло.

А. Петно, ивица по задната лещена капсула към стъкловидното тяло.

В. Белезникава лезия на повърхността на папилата.

С. Мътнини в стъкловидното тяло.

Д. Всичко гореизброено.

\section{9. Персистиращото първично хиперпластично стъкловидно тяло може да се усложни до:}
А. Катаракта.
В. Хеморагии в стъкловидното тяло.
С. Глаукома.
Д. Всичко гореизброено.
Е. A, B.

10. С кое от състоянията трябва да направим диференциална диагноза при персистиращо хиперпластично стъкловидно тяло.
А. Ретинобластом
В. Дисплазията на Reese.
С. Конгенитална катаракта.
Д. Всичко гореизброено.

\begin{tabular}{ll}
\multicolumn{2}{c}{ ОТГОВОР } \\
\hline 1. & А. \\
2. & В. \\
3. & С \\
4. & А. \\
5. & А. \\
6. & Е. \\
7. & Д. \\
8. & Д. \\
9. & Д. \\
10. & Д.
\end{tabular}

